〔報 文〕

\title{
流出原油の経時変化に関する研究
}

\author{
浮上油の化学性の経時変化 (第 2 報)
}

佐野 寛*, 木田 繁*, 相馬芳枝*, 西田修身**

\section{Studies on the Change of Spilled}

Oil with the Time Elapsed (2)

Chemical Change of Floating Oil

by Hiroshi Sano*, Shigeru Honda*, Yoshie Souma*, Osami Nishida**,

\section{1. 緒 言}

海上流出原油の経時変化のうち, 物性の変化に関して は前報1でとり扱ったので, 本報では主として原油を模 成する成分物質の化学变化檤追求する。

石油は非常に多くの炭化水素の複雑な混合物であっ て，ほ上んどガス状の低沸点油分からガソリン分・灯油 分を経て軽油に至るまでの広い沸点範囲をむち，さらに 常圧では热分解するため蒸留することのできない高沸点 成分から成る油分（重油）在，原油に刘しほぼ半量含有 している.

したがって経時変化を把握するためには, あっとも特 徵的な揮発分の段階的損失を明確にとらえるための测定 項目としてガスクロマトグラフィーが重要になる。乙れ は構成油分の変化，特に沙点分布の変化をよく反映する あのと考えられる.

次に，不揮発分の相対的な增大および重合酸化などの 進行にともなって期待される高分子成分の增大を反映す る測定項目としては, 石油エーテル不溶分（ほぼアスフ フルテン分に対応），熱ベンゼン不溶分，残留炭素分， 㧍よび㶮分が注目される。

*工業技術院大阪工業技術試験所 (Government Industrial Research Institute, Osaka)

**神戸商船大学 (Kobe Merchantile Marine University)
油の含有する官能基 $(\mathrm{COOH}, \mathrm{C}=\mathrm{O}$ 等）は前報にすで にのべたように赤外線吸収測定で認められないほど微量 であるが，酸性基のみはかなり少量であ酸価の測定によ って定量できるので, 酸価を测定した.

以上の测定值の相互関係些比較検剠して, 原油構成物 質の経時変化について考察をおこなう。

なお，試料採取については前報と同様の于段によっ た.

\section{2. 実 験}

\section{1 ガスクロマトグラフィー}

石油のガスクロマトグラフィー分析については，JIS に規定はないので, 石油組成分析に関する実験例を調査 した結果， $\mathrm{C}_{2} \sim \mathrm{C}_{7}$ 岑化水素についての藤田 ${ }^{2)}, \mathrm{Martin}^{3}$ の分析, Desty ${ }^{4)}$, Eggertsen ${ }^{51}$ らの全㩲発成分の分析, さらに高澡点留分についての Ogilvie ${ }^{6)}$ ，功力7らの分 析方法など在参考にして次のような測定方法をとった。

陚料 $3 \sim 10 \mu 1$ 老上り，柳本 GC 残畄物除去装置を之 りつけたガスクロマト測定機（柳本GCG-550T）に注人 した．この時の実験条件は次の通りである.

カラム充填剂：シリコンSE30，3\%クロモソルブ W. カラム $: 3 \phi, 2 \mathrm{~m}$

カラム温度: $40^{\circ} \sim 280^{\circ} \mathrm{C}$, 昇温 $8^{\circ} \mathrm{C} / \mathrm{min}$

キァリアガス: $\mathrm{He}$, 压力 $1 \mathrm{~kg} / \mathrm{cm}^{2}$

注入口温度 : $300^{\circ} \mathrm{C}$

検出器: $\mathrm{TCD}, 330^{\circ} \mathrm{C}$

なお，原油の最終回付近の試料およびミナス原油のすべ ての試料は，固化してそのままでは注入するてとができ ないので, 一定量のベンゼンを加えて希釈溶解してから 注射簡に移して注入した。

いずれの場合にも， 3〜4回使用後には残渣除去装置 のフイルター内には多量の残渣分が蓄積し, 急速に感度 が低下するのでしばしばフイルターのグラスウールを交 換した。 


\section{2 石油エーテル不溶分}

石油中に含まれる高分子成分は，一般に溶剂によって 溶解度差があり，分類ないし分別することができるが， 一定した方法は確立していない，アニリン均一溶液形成 の最低温度で表示するアニリン点やや，溶剂ナフサによ って10倍に希积したときに発生する蹜殿物容積で表示す

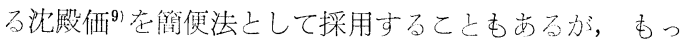
と屯一般的なむのは，軽質油不溶分上して高分子成分资 分離する手段であって，ふつうにアスファルト分の定量 法上して和られる方法である.アスファルト分の定量法 には非常に多種類の方法，すなわち，IP法（英国石油協 会規格, IP : 143/57), UOP 法 (B61-40), DIN 法 (51577), 東大法 ${ }^{101}, \mathrm{BM}$ 法 $^{11}$ などがありそ机らの総合 的な検討 ${ }^{12}$ もおてなわれているので，乙れら在参考之し て次のような方法をとった。

試料約 $1 \mathrm{~g}$ 在 $50 \mathrm{ml}$ ビーカーにはかり上り，50 $0^{\circ} \mathrm{C}$ 前 後に加温した石油エーテル（主成分はへキンンおよびへ プタン） $25 \mathrm{ml}$ 老加え十分にかくはんする． $25^{\circ} \mathrm{C}$ まで 冷却したのち静置して上澄液を沪紙上にあけ，ビーカー に残照する沈殿にさらに室温の石油エーテル $20 \mathrm{ml}$ 歨加 元静置後上澄液を沪過する。 この操作を 2 回以上くり返 す。ビーカーと沪紙とをとり, 乾燥器で $110^{\circ} \mathrm{C} \cdot 30$ 分
以上乾燥し冷却後それぞれを秤量して重量增加の和を求 め，これを石油エーテル不溶分とする。

この操作において, 最初に高温で加える石油エーテル 量を減少させると不溶分は増大するが, 試料に対して十 分に多い石油エーテルを加え机ぞその秤量值は一定し， また洗浄する石油エーテル量は $30^{\circ} \mathrm{C}$ 以下であれば数倍 量使用しても秤量値はほと九ど変動しない13，

\section{3 熱ベンゼン不溶分}

アスファルテンなど高分子性の油分を溶解し去り，非 油性の沈殿物のみ在定量する目的で高い溶解性を示す熱 ベンゼンを溶剂恣便用する。

2.2 で使用した試料を入机たままの同一のビーカー をとり, ベンゼン $25 \mathrm{ml}$ 老加えて加热し, わずかに沸之 うさせたのち液を 2.2 で使用した沪紙上にあける。こ の操作を 2 回以上くりかえす. その後， 2.2 之同様な 操作により残渣分を秤量して熱ベンゼン不溶分とした。

\section{4 残留炭素 (JIS K2270)}

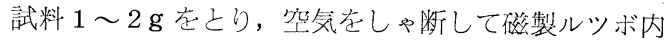
で加愁し残留不揮発分を科量する。詳細は JIS K2270 による。

\section{5 灰分 (JIS K2272)}

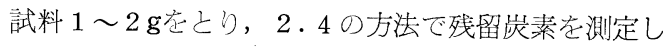
たのち、ルッボのフタを開放して 加熱, 十分に重量が一定値となる まで然焼して，秤量する.

\section{6 全酸価（JIS K2502）}

石油の全酸価は，JIS に求ける “石油筴品中和価試騟方法”14) 亿準 じておてなう。

試料は約 $1 \mathrm{~g}$ 在とり，トルエン およびイソプロパノール1：1混 合溶媒を $25 \mathrm{ml}$ 加えて溶解し,

N/100KOH イソプロパノール溶

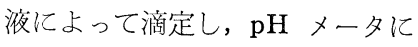
より滴定曲線を描さ, 得られた変 曲点を終点とした。全酸価は, 試 料 $1 \mathrm{~g}$ 中のすべての酸を中和する 亿要する $\mathrm{KOH} の \mathrm{mg}$ 数で表示 する。

\section{3. 結 果}

各試料のガスクロマトグラムの うち, マーバン原油の 0 時間およ び30日間経過試料について測定し たものを図 1 および四 2 亿示す. 原油中の多くの成分のうち, 相対 


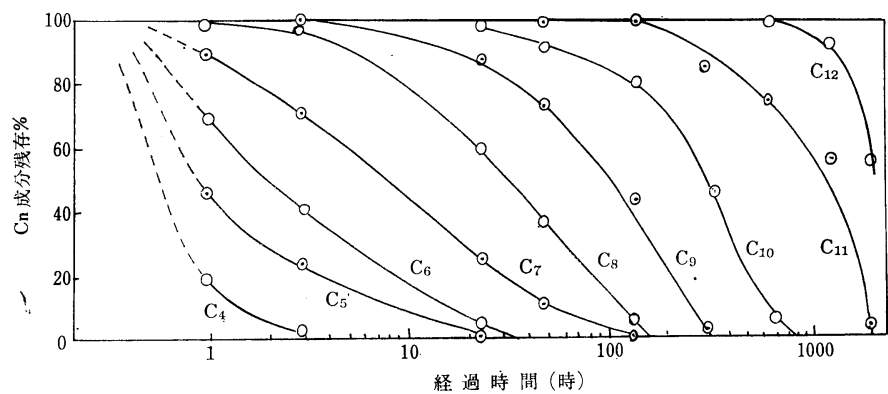

図 3 マーバン原油中炭化水素各成分の消失

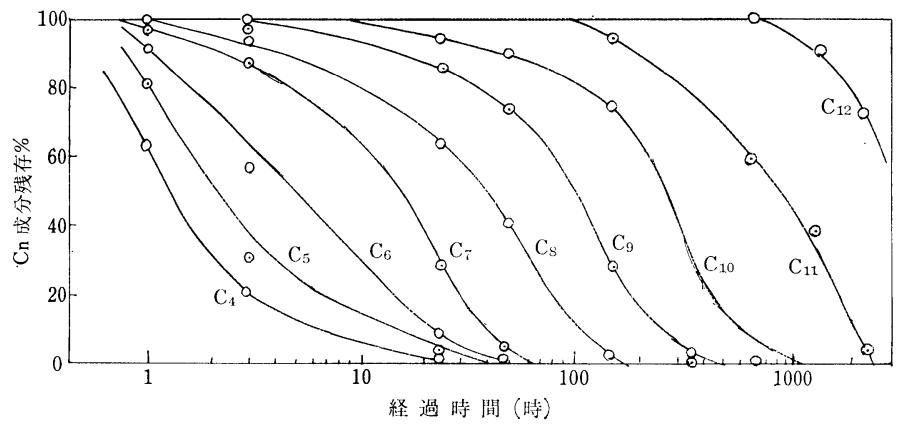

図 4 イラニアン原油中炭化水素各成分の消失

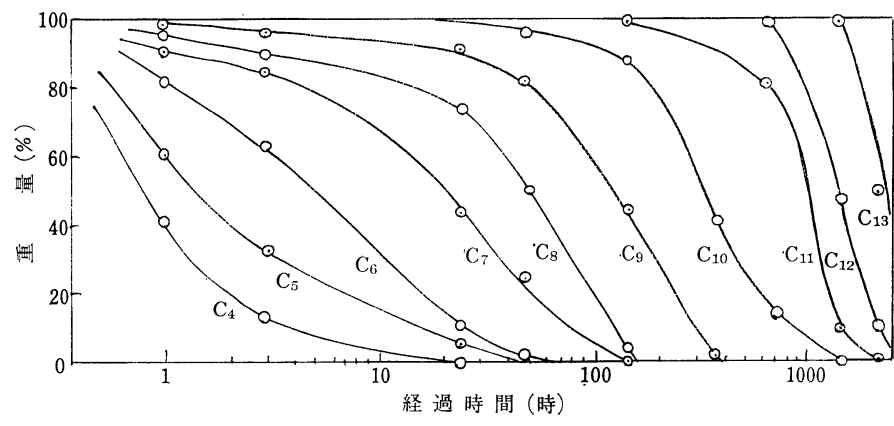

図 5 クエート原油中炭化水素各成分の消失

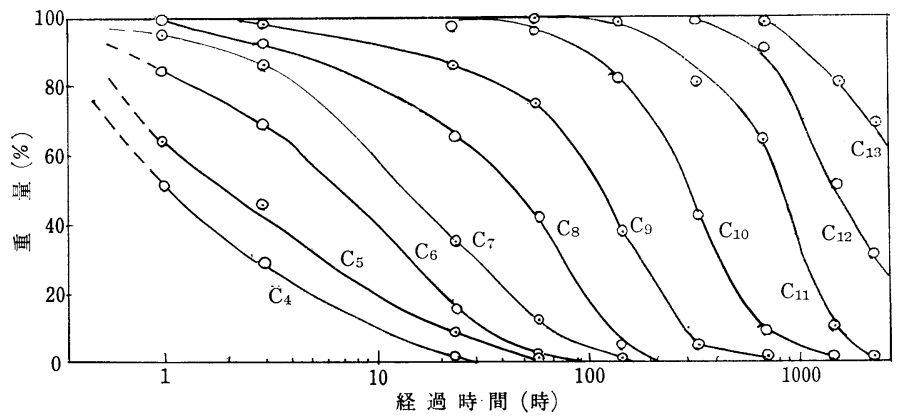

図 6 カフジ原油中炭化水素各成分の消失
的に含有量の多い $\mathrm{n}$-パラフィンが, 図 1 のように沸点順に $\mathrm{n}$-ブタン, $\mathrm{n}$-ペン タン…炭素数の増加する順にしたがっ てそのピークが現れる. 各成分ピーク は，それぞれ既知の $\mathrm{n}$-ブタン， $\mathrm{n}$-ペン タンなどの標準物によって同定するとと ができる. 図 1 と図 2 とを対比すると, $\mathrm{C}_{4} \sim \mathrm{C}_{9}$ 成分は完全に消失し， $\mathrm{C}_{11}$ 以上の 成分むかなり減少しているが， $\mathrm{C}_{15}$ 以上 の成分ピークはほとんよ゙変化していな w.

そこで全試料にわたって変化の非常に 小さいとみられる $\mathrm{C}_{20}$ のピークを基淮と して，減少した各成分の比率を評価する ことが可能になる.すなわち, 炭素数 $\mathrm{n}$ の炭化水素 $\mathrm{C}_{\mathrm{n}}$ のピーク面積を $\mathrm{S}_{\mathrm{n}}, \mathrm{C}_{20}$ のピーク面積を $\mathrm{S}_{20}$ とすると， $\mathrm{C}_{\mathrm{n}}$ 成分 の残存\%は，0時間のときを $100 \%$ とす ると次のようになる。

$$
\mathrm{C}_{\mathrm{n}} \text { 残存 } \%=100 \times \frac{\mathrm{S}_{\mathrm{n}}}{\mathrm{S}_{\mathrm{n}}{ }^{\circ}} / \frac{\mathrm{S}_{20}}{\mathrm{~S}_{20^{\circ}}}
$$

ただし， $\mathrm{S}_{\mathrm{n}}{ }^{\circ}$ および $\mathrm{S}_{20}{ }^{\circ}$ は，それぞれ 0 時 間の之きの $\mathrm{C}_{\mathrm{n}}$ 成分执よ゙ $\mathrm{C}_{20}$ 成分の ピーク面積である.

この算出法にもとづいて, マーバン, イラニアンヘビー, クェート, カフジ, ミナスなど各原油についてそ机ぞれの $\mathrm{C}_{\mathrm{n}}$ 成分の残存率の経時変化在求め，乙れ 在図 3 〜図 7 に示した.

石油エーテル不溶分の測定結果は図 8 に示した。

熱ベンゼン不溶分については，大部分 のものは経時変化開始後長期間まったく 認められなかったが，実験の終期に至っ て多少の正值が出現したので，乙れを図 9 に示した。

残留炭素分は図10に示した。

灰分は熱ベンゼン不溶分上同様，初期 においてまったく認められず，終期にお いてわずかに現れた。 これを図11に示 した.

全酸価については, マーバンおよびカ フジ原油の初期試料は, 全酸価が極度に 低く測定值を得ることができなかった。 またマーバン原油の最終回試料はほほと んどが水分であってトルエン・イソプロ 


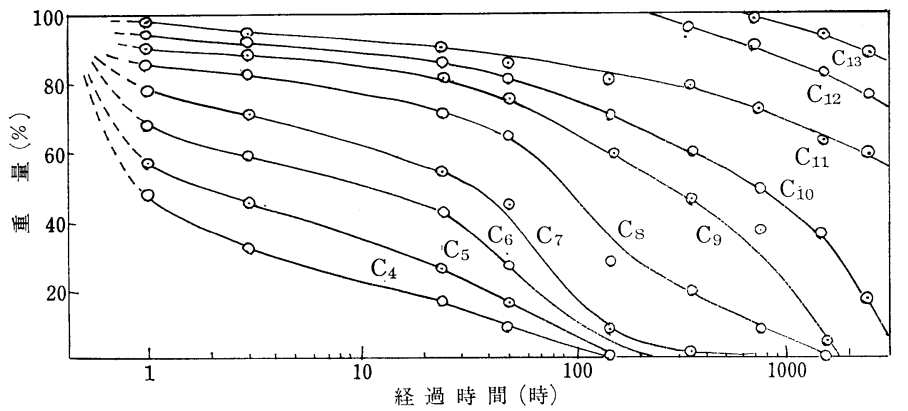

図 7 ミナス原油中炭化水素各成分の消失

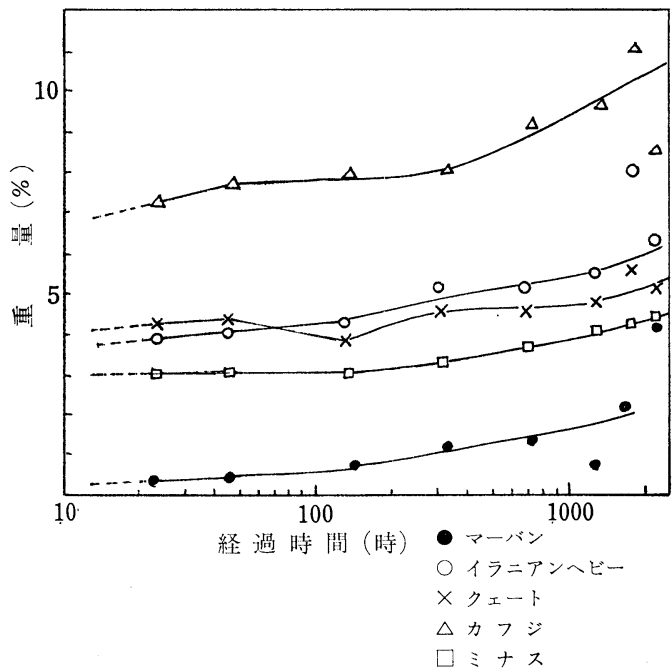

図 8 石油エーテル残渣分の経時变化

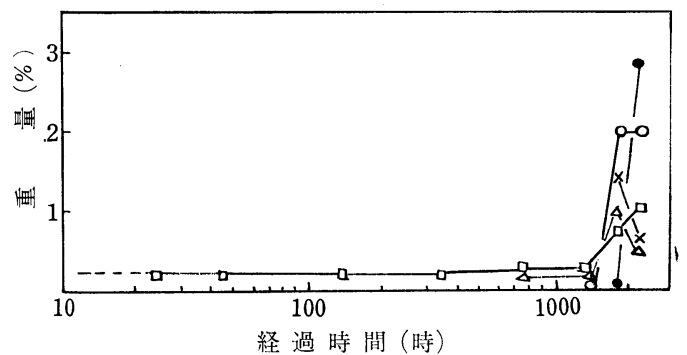

図 9 熱ベンゼン不溶分の経時変化（記号は図 8 と同じ

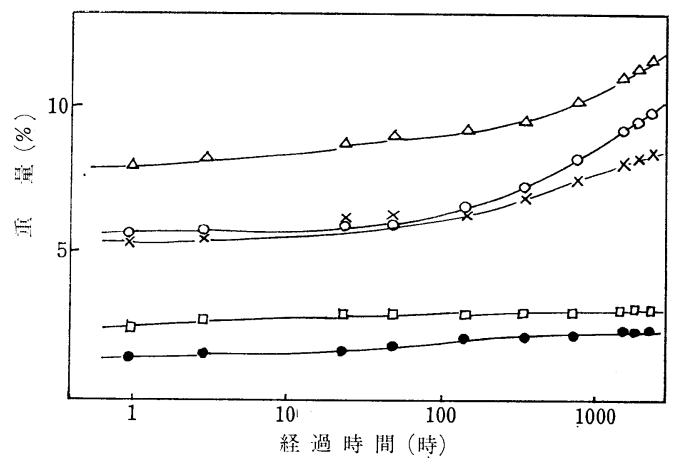

図10 残留炭素分の経時変化（記号は図 8 と同じ）
パノール溶剂によく混合せず測定しなか った.酸価測定の結果は図12に示した。

\section{4. 考 察}

石油の流出時に招ける危険防止，海水 接触時の咛蔵における変性などの研究と しては石油構成物質の変化を追求するこ とが大きな重要性を持っている. 本報に おける実験 2.1 は，主として低沸点揮 発成分の変化に関する有力な知見を与え るものであり，実験 $2.2 \sim 2.5$ は主として高沸点成分・ 不揮発成分の変化に関する知見を与えるあのである. 他 に, 化学的な酸化・重合・分解などによって発生すると 期待される官能基については, 酸価のみが測定されたに とどまった，以下に主要な特性の経時変化について考察 する。

\section{1 揮発成分の変化}

流出油の初期〜中期におけるもっと屯主要な変化は，

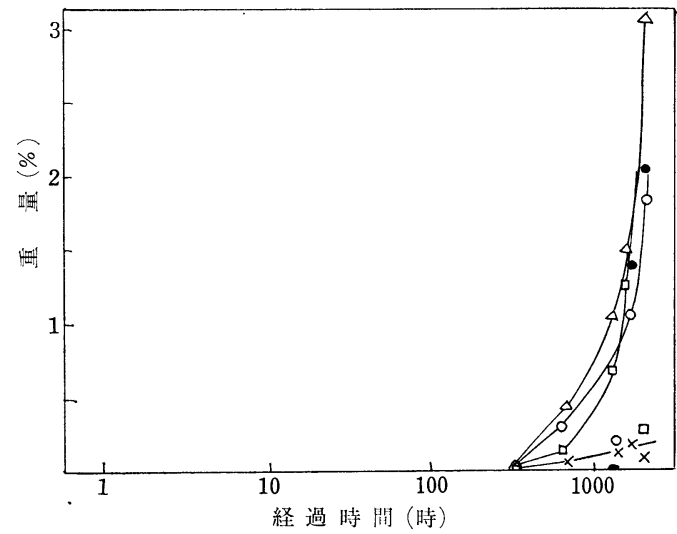

図11 扊分の経時変化（記号は図 8 と同じ）

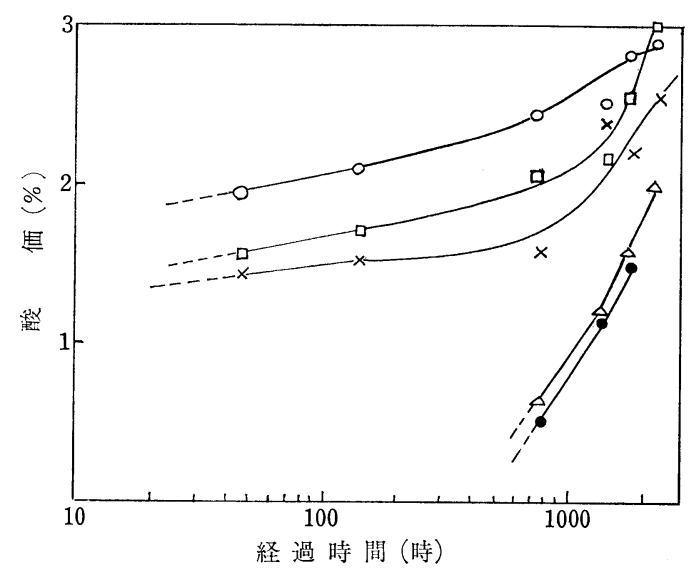

図12 全酸価の経時変化（記号は図 8 と同じ） 
低沸点成分の揊発消失之，そ机にともなう高沸点不揮発 性成分の相対的な濃度上昇である。ガスクロマトグラム によって得られた図 3 ～図 7 の結果によると， $\mathrm{C}_{\mathrm{n}}$ 成分 の揮発消失は, 経過時間に対し䏛膫な対沁が認められ る.すなわち， C 成分 (ブタン) は約 3 時間で消失, $\mathrm{C}_{5}$ 成分 (ペンタン) は 1 日で消失する。 $\mathrm{C}_{9}$ 成分までの いわゆるガソリン・ナフサ分は約 1 週間で消失し， $\mathrm{C}_{10}$ 成分は約 1 月, $\mathrm{C}_{12}$ までのいわゆる灯油分は約 3 力月後 に消失する・したがって 3 力月経過時点では，軽油の燺 散が進行し始好た時点にほぼ相当し，沸点分布からいえ ばまだ重油ていどまでの濃縮に逶していない上いうこ とができる。

ミナス原油のみは，いちじるしく異った曲線（戝 7 ) を示している. とれは陚料が最初から固化しているので 混合が完全におこらないため, 気化が不均一に表層部に おいてのみ多く起こるためであると考元られる, 挨発性 成分が長期にわたって保存されることは，前報”に执い ても引火点の測定值が, 初期在除く上ミナス原油が常に むっ上も低い值を示す事実上一致する・流動性をむった 他の油に抢いては，図3〜図6のように $\mathrm{C}_{\mathrm{n}}$ 成分の消头

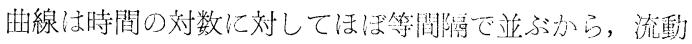
性它失う之これら経時変化の䙺則性は央わ机るもの上考 える必要がある。

な招，実用的な見地加ら石油の各成分の消头在半減期 によって表示, 比較するととは便利である。 C 4 以下の

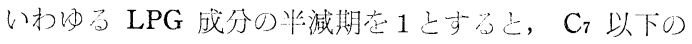
石油エーテル分の半減期活 $10, C_{9}$ 以下のガソリン分の 半隇期は $100, \mathrm{C}_{12}$ 以下の灯油分の半隇期は 1,000 上な り， $\mathrm{C}_{15}$ 前後の軽油分の半減期在外元うに上って推定す る上 10,000 付近上考えるこ上ができる。

この経時変化の実験は，前報”に示したように油膜の 上下が開放されているとはいえ, 油層はかなりの厚さで 保存されているので, 流出油事故のように油層がうすく ひろがっているときには, 各 $\mathrm{C}_{\mathrm{n}}$ 成分の消失速度泳はる 加速くなる上期待さ机る。 关の場合, 各 $\mathrm{C}_{\mathrm{n}}$ 成分の半 減期が一律に一定比で短縮さ机るか否かは，きわわて興 味ある今後の課題である.

\section{2 高沸点揮発成分の变化}

石油中の高分子成分は，貯蔵安定性在左右するスラッ ジ生成の主要因子であり，乙の浮上油経時変化に掠いて あオイルボール生成などに関係があるとして注目されて いる測定項目である.

石油エーテル不溶分はワックス, アスファルテン, カ 一ビン，カーボイドなど石油中のあらゆる高分子成分の 総和量を示すものであり，これらを区別するためには， $\mathrm{n}$-ヘプタン加熱抽出( I ), $\mathrm{n}$-ヘプタン抽出(II), ベン
ゼン熱抽出（III）などが併用されなければならない131.

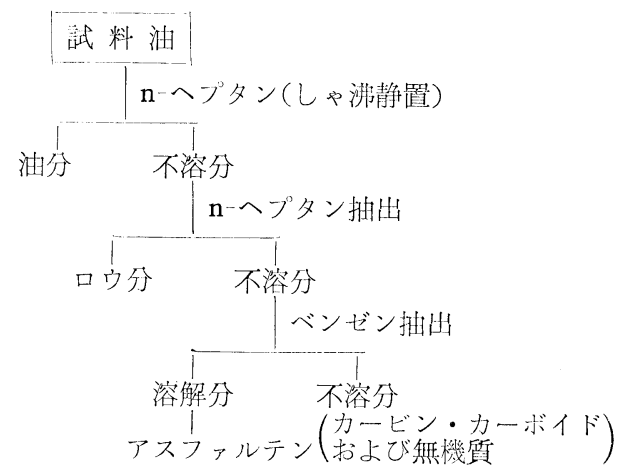

本報注いては，乙れらの詳細な分别在するこ上は目的 ではないので, 石油エーテル残清分としてアスファルテ ンとワックスの総量を求妙た. ミナス原油の場合は, ア スファルテン含行量が少いととで有名なので石油エーテ ル残渣分の大部分はワックス分であろう. 石油エーテル 不溶分は, 前報に扔ける比重抢よび粘度, 本報に招ける 残留炭素分などの経時增加上ほぼ刘伈している.

残留荻素分は，热分解時にアスファルテンから大量に 岑素が析出することからみて石油エーテル不溶分之ほ添 並行すを・ただしアスファルテンの少ないミナス原油の みは刘㐫しない。

熱ベンゼン不溶分は, 浮上油経時実験末期に急速に上 界するが，こ机らの色彩がほ上んど白色であることから 岑素質ではなく, 海水起源の灭分上考えられる。図11亿 示さ机炏分の結果も，ほ涩一玫して未期で急速に增大 している。

一般に流動点は，口ウ分书よびアスファルト分の増大 とと屯に上昇すると信じられているが，本報の不油エー テル不溶分之前報1)の流動点之の関係では雨者は同じ倾 间起示さず，むし万反対の順序になっている部分が多く 見出される。そしてどの場合でも石油エーテル不溶分は せいぜい10\%近くに到達するに過ぎないから，「不油は 放置す机ばアスファルト化しそのために固結する」と考 えるのは不適当である。

\section{3 酸・境基柱变化}

石油は，原則的には中性の炭化水萃加らなり，ほ之ん 上゙酸・塩基成分圶含まないが，長時間の空気扰よび水， 微生物の存在下で酸化や加水分解などが複雑に進行す机 ば，カルボキシル基など種々の極性基を発生すると考え られる。したがってこれらの官能基を定量すれば，経時 変化における重要な指標の一つとすることができる。し かし, 先に赤外吸収において水分の增加以外にほとんど 特性吸収の增減が認められなかったととをのべた。した 
がって大量の官能基の発生, 消滅はないとみてよい.

浮上油の全酸価の変化の測定例としては, 先にインド ネシア・デュリー原油に関する実験例があり(15)それによ ると全酸価は約 4 から 7.2 まで増大することが測定され た、ただし，その実験ではビーカ一中で通気かくはんす るものであって，本報のように開放海水面之連通した水 上接触し絶えず更新する海水によって洗浄されている条 件とは非常に異っているから，直接に比較・対応させる ことはできない。

困12に示さ机た結果では約 1,000時間までは経過時間 の対数に対してほぼ直線的に増加するが，1,000時間経 過後から全酸価は急上昇する。乙の末期における急上昇 は 4.2 の測定值においてもかなり認められるものであ って，しかむ 4.1 における揮発分の結果からは何ら急 激な変化を伴っていないから濃縮による変化とみること はできず，むしろ酸化・重合・加水分解など化学的な変 化が起き始めているとみることができる.
<参考文献 $>$

1) 本誌 (第 1 報)

2) 藤田, 佐織, 菊地, 石油学会誌 4, 298 (1961)

3) R. L. Martin, J. Winters, Anal. Chem., 31, 1954 (1959)

4) O. H. Desty, B. H. F. Whyman, Anal. Chem., 29 320 (1957)

5) F. T. Eggertsen, S. Groennings, Anal. Chem., 30, 20 (1958)

6) J. L. Ogilvie, M. C. Simmons, Anal. Chem., 30, 25 (1958)

7) 功力, 藤本, 池田, 田村, 石油学会誌 7, 26（1964）

8) ASTM D 611, JIS K 2256

9) ASTM D 91, JIS K 2504

10）安東新午, 旭硝子工業奨励会報告 10,1（1964）, 石油 学会 6 部会, 石油学会誌 7, (3) 178 (1964)

11) R. L. Hubbard, Anal. Chem., 20, (5)460 (1948)

12）アスファルテン定量法専問委員会, 石油学会誌 11(3) 190 (1968)

13）小野達雄, 石油学会誌 14, 504 (1971)

14) JIS K 2502 (1968)

15）科学技術庁研究調整局 “船舶廃油による海水污濁に関 する特別研究報告書”（1968）

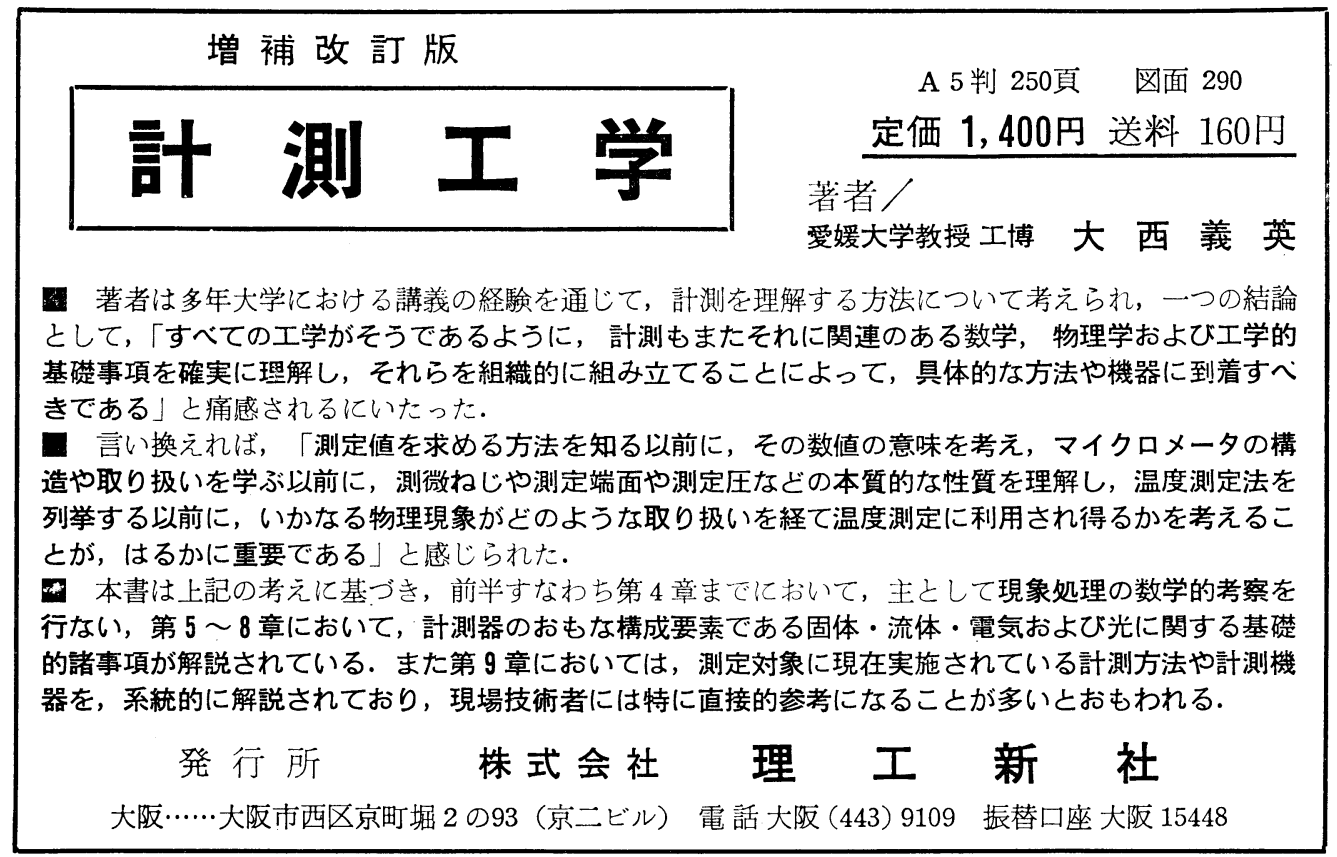

